\title{
情報通信理論によるふるい分けモデルの検討 一三輪の確率モデルの検証と展開一
}

\section{The Investigation of a Screening Model by the Information Theory -Verification and Development of Miwa's Probability Model-}

\author{
尾崎 都司正 ${ }^{*}$, 三輪茂 雄 ${ }^{* *}$, 原敬 $* *$ \\ Toshimasa OZAKI* ${ }^{*}$ Shigeo MIWA**, Kei HARA**
}

\begin{abstract}
Powder technology requires fusion with other technologies in order to reduce environmental impacts. There is no definitive screening model, even in the screening process, in powder technology. In this paper, the modeling of a screening process is tried by using information theory. The obtained equation is identical to Miwa'sprobability model, which includes previous research on the screening process introduced into screening time. In addition, the relationship between the residue probability and the screening time can be derived by information theory. It is shown that the separation of screening is not so complete in limited screening time, and the way of obtaining the particle distribution is proposed. This research shows that the screening process is the same as the transmission of information and that the conception of other engineering is useful to systematize existing knowledge and promote the fusion of technologies.
\end{abstract}

Key Words : Screening, Information Theory, Probability Model, Particle Size Distribution, Particle Size Analysis

\section{1. 緒 言}

地球環境問題への対応が世界的に喫急の課題であ り，エネルギーのみならず素材開発の分野においても ライフサイクルアセスメントへの対応が求められてい る。このため, 環境負荷の軽減を目指した高機能材料 の開発にあたっては, 多くの素材が粉体形態であると ころから，粉体分野は領域を超えた技術の融合が必要 とされている。最近, 計算科学の分野でも粉体の現象 を扱う試みがなされ，粉体に関する研究はサイエンス の様相を呈している。

\footnotetext{
1997 年 2 月 12 日受付

* (搳関西新技術研究所 情報通信研究センター （テ600 京都市下京区中堂寺南町 17 京都リサーチパーク内） TEL $075-322-6826$

Information Communication Res. Center, Kansai Res. Inst. (Kyoto Res. Park 17, Chudoji Minami-machi, Shimogyo-ku Kyoto 600)

**同志社大学工学部

（神600-03 京都府京田辺市多々羅谷）TEL 0774-65-6596

Fac. of Eng. Doshisha Univ.

(Tataradani Kyotanabe-shi, Kyoto 610-03)
}

基礎的な粉体の分離操作である粉体のふるい分け

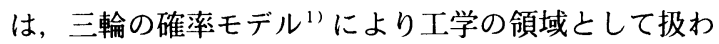
れ，ふるい分け機械の設計・操作に格段の進歩をもた らしている。しかし，三輪以後，ふるい分けに関する 研究は進展していない状況である。

本稿は, ふるい分けの過程の体系化を目的として, 情報通信という他の工学の視点からふるい分け過程の モデル化を行い，従来のふるい分けに関する速度論的 研究との比較を試みた。さらに，一定時間のふるい分 けによる不完全な粒度測定に関して, 粒度分布を推算 する方法についても検討した。

\section{2. 従来のふるい分けモデル}

\section{1 三輪の確率モデル ${ }^{1 \sim 31}$}

目開きに対して網線の太さが非常に小さいとき, Gaudinは目開き $a$ の正方形の網目に直径 $x$ の球状粒子 が，まったく網のどこにもぶつからずに通過する粒子 の通過確率を, 網目の全面積 $a^{2}$ に対する通過可能面 積 $(a-x)^{2}$ の比によって定義した。 
Tabie 1. Previous studies of screening ${ }^{2,11}$

\begin{tabular}{|c|c|c|}
\hline Warner & 1924 & Qualitative explanation concerning a particle passing \\
\hline Stepheson & 1926 & Irregular description of a passing speed through a net \\
\hline Andreasen & 1927 & $\frac{\mathrm{d} R}{\mathrm{~d} t}=-q \cdot R \quad$ or $\quad R=R_{0} \exp (-q \cdot t)$ \\
\hline Yamaguchi & 1927 & $\log y=a+n \cdot \log t$ \\
\hline Heywood & 1938 & $\frac{\mathrm{d} R}{\mathrm{~d} t}=-C \frac{1}{t} \quad$ or $\quad R=C^{\prime}-C \ln t$ \\
\hline Gaudin & 1939 & $P=\left(\frac{a-x}{a}\right)^{2}$ \\
\hline АбраМоВич & 1940 & $R=\exp \left(-k t^{\mathrm{n}}\right)$ \\
\hline Gulink & 1943 & Empirical formula of a change of time to the cumulative passing \\
\hline Fagerholt & 1945 & $R_{1}=R_{\infty}+\frac{b}{2} \sqrt{\frac{\pi}{r t}}$ \\
\hline Kammholz & 1953 & $\frac{\mathrm{d} y}{\mathrm{~d} t}=-y \cdot C(t) \quad$ or $\quad R=\exp \left(-K \cdot t^{m}\right)$ \\
\hline Ide & 1954 & $1-\frac{w_{t}}{w_{\infty}}=\exp \left(-\frac{t}{t}\right)$ \\
\hline Whitby & 1958 & $y=\alpha \cdot t^{\beta}$ \\
\hline Непомн я ши й & 1960 & $\frac{\partial w}{\partial t}=\frac{1}{2} b \frac{\partial^{2} w}{\partial z^{2}} \quad W=1-\frac{2}{\sqrt{\pi}} \int_{0}^{\frac{-0}{\sqrt{2 \mathrm{bt}}}} \exp \left(-x^{2}\right) \mathrm{d} x$ \\
\hline Bodziony & 1961 & $V(x \cdot t)=\int_{x \min }^{x \operatorname{man}} C(x \cdot t) \mathrm{d} x$ \\
\hline Mizutani & 1963 & $\frac{\mathrm{d} R}{\mathrm{~d} t}=-K \cdot R \quad$ or \\
\hline
\end{tabular}

Note 1. Research of Yamaguchi includes an error in the treatment of feed weight.

Note 2. Research of Heywood contains an assumption that the passing quantity in unit time does not depend on an opening of net.

Note 3. Character $R$ shows a residual rate on a net of particles.

$$
P=\left(\frac{a-x}{a}\right)^{2} \quad(x<a)
$$

しかし，実際のふるい分け操作では網目は歪んで正 方形ではなく，粒子形状も複雑であるところから， 個々の粒子の通過過程に対して Eq. (1) が適用しうる ものとは考えられない。著者の一人は，ふるい分け過 程はきわめて多数の粒子と網目とが関与する統計的な 現象であり，Gaudinの粒子通過確率をもとに粒子が 網と衝突する回数を試行数と定義して, 試行数 $i$ にお ける網上残留確率 $\boldsymbol{r}_{\mathrm{i}}$ を次式で示した。2,3)

$$
r_{\mathrm{i}}=\left\{1-\left(\frac{a-x}{a}\right)^{2}\right\}^{\mathrm{i}} \quad(x<\mathrm{a})
$$

Taylor 展開による第 1 項でEq. (2) を近似すること により, 次のようなふるい分け過程における粒子と網 目の関係式を提案している。

$$
r_{\mathrm{i}} \cong \exp \left\{-i\left(\frac{a-x}{a}\right)^{2}\right\}
$$

Eq.(2) あるいはEq.(3) における網上残留率 $r_{\mathrm{i}}$ が試行 数 $i$ の関数になり, $i$ が 20 以上になれば両式の差は小 さく，実用上Eq.(3) が利用できる。

さらに, $\left(i / a^{2}\right)=\left(1 / 2 \sigma^{2}\right)$ とすると, このEq.(3) か ら

$$
r_{\mathrm{i}}=\sqrt{2 \pi} \sigma \frac{1}{\sqrt{2 \pi} \sigma} \exp \left\{-\frac{(a-x)^{2}}{2 \sigma^{2}}\right\},(x<a)
$$

が得られる。ふるい分けにおいては, 網上残留率 $r_{\mathrm{i}}$ は部分分離効率曲線となり, 正規分布の山形の半分で 表示できる ${ }^{1 \sim 3)}$ 。

しかし, Eq. (3) は式の変形に依存するきらいがあ り, また，ふるい分け時間をパラメータとした従来の ふるい分け過程に関する研究との関係が明示的でない という欠点がある。

\section{2 三輪以外のふるい分けの研究 ${ }^{2 ， 4)}$}

時間経過に関するふるい分けの研究は，ふるい分け の速度的な基礎づけとして重要であり， Table 1 に示 したように種々の研究が行われている。研究の特徴 
は, 網目よりはるかに小さい粒子と比較的大きい粒 子の通過する，2つの過程に分けられる点にある。 前者は, Andreasen, Аб $\mathrm{p} \mathrm{aМоВич,}$ 水谷らのモデ ルであり, 後者は, Heywood, Fagerholt, 井出, Kammholz, Whitby らのモデルである。山口や Heywood の研究は，供給量や仮定に問題がある。 また, Непомнящий は網と粒子の視点ではなく， Bodziony のモデルは数学的に緻密であるが, 明確な 結論に達していない。ふるい分けは古くから知られて いる操作であるが, このように法則性が体系化されて いない状況である。

\section{3．情報理論によるふるい分けモデル}

\section{1 情報エントロピーによる均一粒子のふるい分 け過程}

（1）ふるい分け過程と情報エントロピー

ふるいの網上に供給された粒子は，網を通過するか それとも網上に残留するかの 2 つ事象が生起する。 粒子を供給する前では，粒子径 $x$ が網の目開き $a$ より も大きいか, 小さいかについての情報がないため不確 実性が大きい。

このように，一枚のふるいの網に供給される粒度を 情報源と考えると，情報量の授受によって不確実性の 解消が可能であるところから，情報理論を利用したふ るい分け過程のアプローチが可能と考えられる ${ }^{5)} 。$

いま，2枚のふるいの網を用い，一枚目のふるいを 通過した粒子は，2枚目の網には残留すると考える。 粒子が各網上に残留する生起確率，すなわち網上残留 率をそれぞれ $P_{1}, P_{2}$ とすると, シャノンの情報理 論 ${ }^{5)}$ から不確実性が解消できるとされる情報量 $H$ (工 ントロピー）は次式で表される。

$$
H=-\left(P_{1} \log P_{1}+P_{2} \log P_{2}\right)
$$

但し， $P_{1}+P_{2}=1$ である。ふるい分けが完了した時点 では微小変化における $\delta H に$ 変化がなく, Eq. (5) の変 分はゼロとなる。

$$
\delta H=-\sum_{j=1}^{2}\left(\log P_{\mathrm{j}}+1\right) \delta P_{\mathrm{j}}=0
$$

Eq.(5) の条件から, 次式を得る。

$$
\sum_{j=1}^{2} \delta P_{j}=0
$$

目開きや粒子径の情報がなければ，不確実性が最大と
なり，このときエントロピー最大化原理から $P_{1}=P_{2}$ $=1 / 2$ が得られ，ふるい分けは 2 分割されることが示 される。従って, 情報エントロピーの最大化がふるい 分けの一つの式となる。

\section{（2）ふるい分け過程}

網の目開き $a$ より小さい粒子は一回の衝突で，一義 的に網を通過するのではなく，通過しにくさに難易度 がある。いま, 直径 $x$ の球状粒子 1 個が 1 回の衝突で $j$ なる網の通過のしにくさを尺度 $V_{\mathrm{j}}$ で表すことにす る。この尺度は, 網の目開きと粒子径のみに依存し， 衝突の回数に関わらず一定である。

$$
V_{\mathrm{j}}=1-\left[\frac{a_{\mathrm{j}}-x}{a_{\mathrm{j}}}\right]^{2}, \quad(j=1,2)
$$

網上残留率 $P_{\mathrm{i}}$ と Eq. (8) の尺度との積 $E$ は通過しにく さの期待值となり，ふるい分けが完了した時点では微 小変化における $\delta E$ に変化がなく, Eq $(9)$ の変分もゼ ロとなる。

$$
\delta E=\sum_{\mathrm{j}=1}^{2} \delta\left(V_{\mathrm{j}} P_{\mathrm{j}}\right)=\sum_{\mathrm{j}=1}^{2} V_{\mathrm{j}} \delta P_{\mathrm{j}}=0
$$

Eqs. (7)，（9）に未定の定数 $\alpha^{*} ， \beta$ を乗じ，Eq. (6) に加えると

$$
\sum_{\mathrm{j}=1}^{2}\left(-\log P_{\mathrm{j}}+\alpha+\beta V_{\mathrm{j}}\right) \delta P_{\mathrm{j}}=0, \quad\left(\alpha=\alpha^{*}-1\right)
$$

が得られる。任意の $\delta P_{\mathrm{j}}$ に対して上式が成り立つため

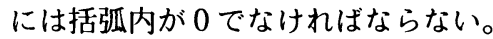

$$
\log P_{\mathrm{j}}=\alpha+\beta V_{\mathrm{j}}, \quad(j=1,2)
$$

$\alpha$ については不定であり， $\alpha=-\beta$ とすると, $j$ なる網 の網上残留率 $P_{\mathrm{j}}$ は Eq. (3) と同型となる。

$$
P_{\mathrm{j}}=\exp \left\{-\beta\left(\frac{a_{\mathrm{j}}-x}{a_{\mathrm{j}}}\right)^{2}\right\}
$$

なお，粒子が目開き $a$ のふるいから得られる情報量 $-\log P$ は，粒子の通過しやすさに比例する。この係 数 $\beta$ は粒子の通過のし易さを情報量に換算するもので ある。 $a, x$ を一定とすると, ふるいから得られる網 目に関する情報量が大きくなれば，網上残留率が小さ くなり， $\beta$ は粒子が網を選好する機会の増大を表し， 三輪の試行数と同じであると考えられる。従って, $\beta>0$ でなければならない。本情報エントロピー法 は, 粒子がGaudinの条件を満足するような挙動を示 


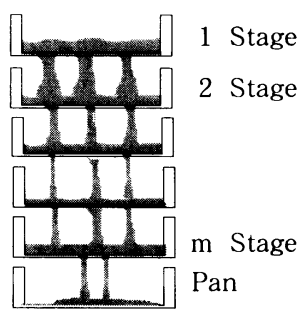

Fig. 1 Batch Screening

す分布状態の中から最も生起確率の高い分布を誘導す るものであり，ふるい分けでは正規分布となってい る。

ふるい分けの基本的関係は, Eq. (3) となり, 著者 の一人は帰納的に Eq. (3) を誘導したが, 演繹的にも 誘導が可能であることが明らかにされた。

\section{2 情報理論による動的ふるい分け過程}

粒子径 $x$ の粒子が目開き $a_{\mathrm{i}}$ の網に供給されたとき の, 網上残留率の動的変化を検討する。最上段に供給 された粒子がm段目の目開きよりも小さいものとし, かつ上段の粒子数あるいは粒子重量を 1 としても他に 影響を与えないことから, 時間 $t$ における網上残留率 を $y_{1}$ とすると, 初期の投入量は $y_{0}=(1,0, \cdots, 0,0)^{\mathrm{T}}$ で表 すことができる。

最上段に供給された粒子は，次の試行で最上段に滞 留するものと， 2 段目に落下するものとに分かれる。 粒子は, 試行数が増加すると, もともと網上に滞留し たところに上の段から落下量が加わって滞留するもの と落下するものとに分かれてゆく。（Fig. 1参照）

試行数 $\beta$ を $\beta=\xi_{a} t$, 時間 $t$ における $\mathrm{j}$ 段の網上残留 率を $y_{\mathrm{lj}}$ で表し, $\mathrm{m}+1$ 段の多段回分ふるい分けを再び 情報理論から考える。時間 $t-1$ での情報源の $\mathrm{i}$ 段か ら情報 $c_{\mathrm{i}}$ が伝送されて時間 $t$ での情報源の $\mathrm{j}$ 段の情報 $d_{\mathrm{j}}$ となったとき, 次の通信路方程式 ${ }^{6)}$ が成立する。

$$
\begin{aligned}
& \sum_{\mathrm{i}=1}^{\mathrm{m}+1} A\left(d_{\mathrm{j}} \mid c_{\mathrm{i}}\right) \cdot P\left(c_{\mathrm{j}}\right)= \\
& P\left(d_{\mathrm{j}}\right), \quad(j=1,2, \cdots, m+1)
\end{aligned}
$$

$\mathrm{j}$ 段のふるいの単位時間当たり通過しにくさ $V_{\mathrm{j}}$ を 用いると, 情報源 $i \mathbf{E}^{-}$の網上残留率 $y_{\mathrm{t}-1, \mathrm{i}}$ をむつ情報が 送信されたとき，受信側における $\mathrm{j}$ 段の網上残留率 $y_{\mathrm{t}, \mathrm{j}}$ との関係は, Eq.(13) から次式が誘導できる。

$$
\begin{aligned}
& \left(\begin{array}{c}
y_{\mathrm{t}, 1} \\
y_{\mathrm{t}, 2} \\
y_{\mathrm{t}, 3} \\
\vdots \\
y_{\mathrm{t}, \mathrm{m}-1}
\end{array}\right)=\left(\begin{array}{ccccc}
V_{1} & 0 & 0 & \cdots & 0 \\
1-V_{1} & V_{2} & 0 & \cdots & \vdots \\
0 & 1-V_{2} & V_{3} & & \vdots \\
\vdots & \ddots & \ddots & \ddots & 0 \\
0 & 0 & 0 & 1-V_{\mathrm{m}} & 1
\end{array}\right) *\left(\begin{array}{c}
y_{\mathrm{t}-1,1} \\
y_{\mathrm{t}-1,2} \\
y_{\mathrm{t}-1,3} \\
\vdots \\
y_{\mathrm{t}-1, \mathrm{~m}+1}
\end{array}\right) \\
& =A^{t *}\left(\begin{array}{c}
1 \\
0 \\
0 \\
\vdots \\
0
\end{array}\right) \\
& V_{\mathrm{j}}=1-\xi_{\mathrm{j}}\left(\frac{a_{\mathrm{j}}-x}{a_{\mathrm{j}}}\right)^{2}
\end{aligned}
$$

すなわち, 多段回分式ふるい分け操作は通信路行列 $\boldsymbol{A}$ をもちいて $\boldsymbol{y}_{\mathrm{t}}=\boldsymbol{A} \boldsymbol{y}_{\mathrm{t}-1}$ となり，ふるい分けが進行す るに伴って, 不確実性が減少していく状況を表してい る。この行列の解は帰納法 ${ }^{7}$ によって求めることがで きる (Appendix 1)。

( I ) 最上段のふるい $\mathrm{j}=1$

$$
\begin{aligned}
y_{\mathrm{t}, 1} & =V_{1} y_{\mathrm{t}-1,1}=\cdots=V_{\mathrm{1}}^{\mathrm{t}} y_{0,1}=V_{1}^{\mathrm{t}} \\
& =\exp \left\{-\xi_{1}\left(1-\frac{x}{a_{1}}\right)^{2} t\right\}
\end{aligned}
$$

これは，Eq.(3) と同じである。

(II) 2 段目のふるい

$$
y_{\mathrm{t}, 2}=\left(1-V_{1}\right)\left(\frac{V_{2}^{\mathrm{t}}}{V_{2}-V_{1}}+\frac{V_{1}^{\mathrm{t}}}{V_{1}-V_{2}}\right)
$$

（III） $\mathrm{j}$ 段目のふるい

$$
y_{\mathrm{t}, \mathrm{j}}=\prod_{\mathrm{i}=1}^{\mathrm{j}-1}\left(1-V_{\mathrm{i}}\right) \sum_{k=1}^{\mathrm{j}} \frac{V_{k}^{\mathrm{t}}}{\prod_{\mathrm{l}=1,1 \neq k}^{\mathrm{j}}\left(V_{k}-V_{\mathrm{l}}\right)}
$$

(IV) 受血

$$
\begin{array}{r}
y_{\mathrm{t}, \mathrm{m}+1}=1-\prod_{\mathrm{i}=1}^{\mathrm{m}}\left(1-V_{\mathrm{i}}\right) \cdot\left\{\frac{V_{1}^{\mathrm{t}}}{\left(V_{1}-V_{2}\right) \cdots\left(V_{1}-V_{\mathrm{m}}\right)\left(1-V_{1}\right)}+\right. \\
\cdots \cdots \cdots \cdots \cdots \cdots \cdots \cdots \cdots \cdots \cdots \cdots \cdots \cdots \cdots \cdots \cdots \cdots \cdots \cdots \cdots \cdots \cdots \cdots+ \\
\left.\frac{V_{\mathrm{m}}^{\mathrm{t}}}{\left(V_{\mathrm{m}}-V_{1}\right) \cdots\left(V_{\mathrm{m}}-V_{\mathrm{m}-1}\right)\left(1-V_{\mathrm{m}}\right)}\right\}
\end{array}
$$

ところで, 従来のふるい分けによる粒度測定では, 設定時間の根拠が曖昧であり，分離が不完全な場合に ついての対応策もないようである。しかし， Eqs. （15）（18）から，任意のふるい段における網上残 留率を解析的に求めることができ，その結果はふるい 
Table 2. Calculation result based on the Miwa's model

\begin{tabular}{cccrrrrrr}
\hline \multirow{2}{*}{$\begin{array}{c}\text { Opening } \\
(\mu \mathrm{m})\end{array}$} & Feed & \multicolumn{7}{c}{ Screening time $(\mathrm{s})$} \\
\cline { 3 - 9 } & Size $(\%)$ & \multicolumn{1}{c}{0} & \multicolumn{1}{c}{60} & 180 & 300 & 900 & 3600 & 7200 \\
\hline 420 & 2.2 & 100.00 & 4.16 & 3.10 & 2.86 & 2.56 & 2.37 & 2.32 \\
350 & 5.0 & & 12.08 & 7.91 & 7.02 & 6.07 & 5.56 & 5.39 \\
297 & 12.8 & & 29.08 & 18.14 & 15.91 & 13.80 & 13.07 & 12.95 \\
250 & 27.7 & & 51.36 & 40.67 & 37.54 & 33.18 & 30.36 & 29.57 \\
210 & 49.4 & & 67.99 & 57.82 & 55.66 & 52.94 & 51.19 & 50.67 \\
177 & 62.1 & & 82.52 & 72.12 & 69.12 & 65.60 & 63.72 & 63.22 \\
149 & 76.7 & & 90.88 & 85.25 & 83.65 & 80.96 & 78.84 & 78.21 \\
125 & 86.2 & & 95.44 & 91.29 & 90.03 & 88.36 & 87.29 & 86.99 \\
\hline- & 100.0 & 100.00 & 100.00 & 100.00 & 100.00 & 100.00 & 100.00 & 100.00 \\
\hline
\end{tabular}

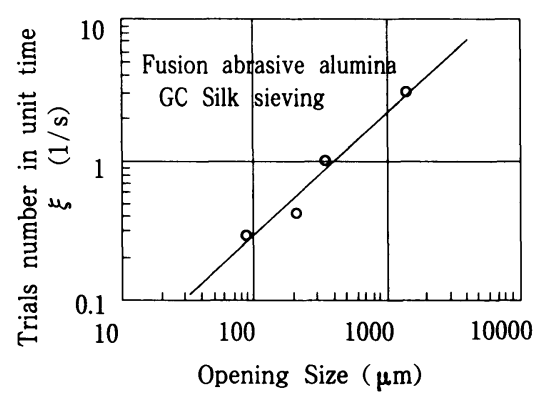

Fig. 2 Trials number in unit time

分けの精度に関する知見や，粒度分布を求める方法も 示唆できると考えられる。

\section{4. 数 值 解}

\section{1 単位時間あたりの試行数 $\xi$ の決定}

Eqs.（15)〜（18）を用いて網上残留率の時間依存性 を解析的に求めるには，単位時間当たりの試行数 $\xi を$ 決定する必要がある。試行数 $\xi$ は粒子形状や網の形状 に依存する量である。

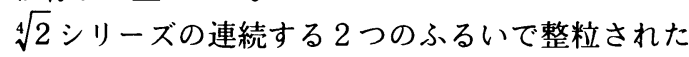
分布をもつ粒子の残留率 $R_{\mathrm{t}, a_{i}}$ は，ふるるい分け時間が大 きいところで直線性の成立が著者の一人によって確認 されている3)。

$$
\ln R_{\mathrm{t}, a_{i}}=A_{a_{i}}^{\prime}-B_{a_{i}}^{\prime} \ln \xi_{a_{i}} t
$$

$A_{a_{i}}^{\prime}, B_{a_{i}}^{\prime}, \quad \xi_{a_{i}}$ は時間に依存しない定数であるか ら，ふるい分け時間 $t$ と網上残留率の測定をもとにし て, 非線型パラメー夕決定法により各係数を求めるこ とができる。本研究では，比較的簡単なマルカート法 を採用した。目開き $88,210 ， 350 ， 1410 \mu \mathrm{m}$ の $\mathrm{GC}$ 絹ふるいを用い, 溶融アルミナ系研磨材での実験

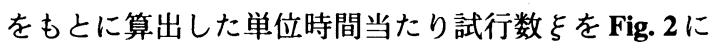
示す。

\section{2 数值シミュレーション}

粒度分布が既知の溶融アルミナ系研磨材を用い, 目 開き $125 ， 149 ， 177 ， 210 ， 250 ， 297 ， 350 ， 420$ $\mu \mathrm{m}$ の G C 絹ふるいによる網上残留率を Eq.(19)によ って求めた。なお，重量基準の粒度分布を個数基準に

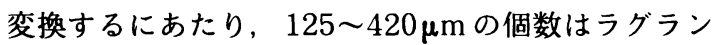
シュュの補間法で求め, 両端は対数正規分布を仮定して 個数基準頻度分布関数を求めた。また，単位時間の試 行数は, 先のグラフから得た回帰式から算出した。各 網上残留率の時間的変化を Table 2 に示す。

網目より比較的小さい粒子が 60 秒ぐらいのふるい 分け時間でほぼ落下していることが伺える。しかし, 粒度分布がFeed Sizeに収斂するには，ふるい分け時 間を大きくすることが必要であるところから，前者と のふるい分け機構の違いが示唆される。実際のふるい 分け機構では，ふるいの網上で粒子が偏析し，大きい 粒子の上に積層した小さい粒子は，ふるい分けが容易 でないために，二つのふるい分け機構を持つと考えら れる。本シミュレーションモデルは, 同一網の残留確 率は時間の経過とともに幾何級数的に小さくなる Eq.

(3) がベースである。

Table 2は，この幾何級数の特性を利用することに より, 実際のふるい分け機構の違いを表すと考える。

\section{5. ふるい分けモテルの考察}

\section{1 三輪の確率モテルと従来の研究との比較}

\section{(1) 整粒された粒子のふるい分け}

Eq.(3)に，試行数として $\mathrm{i}=\xi_{a} t$ を用いて，微小時 間における網上残留率 $y_{\mathrm{t}, 1}$ をとると Eq. (15) から Andreasen ${ }^{2)}$ や水谷と同型の式 ${ }^{4)}$ が得られる。 


$$
\frac{\mathrm{d} y_{\mathrm{t}, 1}}{\mathrm{~d} t}=\xi_{a_{\mathrm{i}}}\left(\frac{a_{1}-x}{a_{1}}\right)^{2} y_{\mathrm{t}, 1}=-K_{1} y_{\mathrm{t}, 1}
$$

Andreasen や水谷のモデルに比べ，三輪の確率モ テルでは比例定数 $K_{1}$ が目開きや粒子径の関数として 明確な形で表わされている。また，粒度分布の狭い領 域のふるい分け過程では，粒径の小さい粒子と粒径の 大きい粒子がランダムにふるい分けられるが，粒径の 小さい粒子の通過が比較的多くなることから， $K_{1}=$ $\xi_{a}\left\{1-\left(x / a_{1}\right)^{2}\right\}$ の值は漸減して一定と考えることはで きない。もし，Andreasen や水谷のように比例定数 を一定とすると，初期の細かい粒子の通過には適合す るけれども大きい粒子の通過には適合しなくなる。 Kammholz, АбраМоВич らのモデルに示された $t^{\mathrm{n}}$ の指数部分が $\mathrm{n} \leq 1$ となるのは, 細かい粒子の通過に 対する粒子径の影響を時間の項で補正したためと考え られる。しかし，三輪の確率モデルは，粒子径の影響 を含み, 網目よりはるかに小さい粒子が通過する過程 の網上残留率を数理的に説明でき，その合理性に秀で ていると考えられる。

\section{（2）粒度分布をもつ粒子のふるい分け}

広い粒度分布 $f(x)$ をもつ粒子の網上残留率について は, 次式が成立する ${ }^{2)}$ 。

$$
\begin{gathered}
R_{\mathrm{i}}=\frac{\int_{x_{\text {min }}}^{x_{\max }} x^{3} f(x) \exp \left\{-i\left(\frac{a-x}{a}\right)^{2}\right\} \mathrm{d} x}{\int_{x_{\text {min }}}^{x_{\max }} x^{3} f(x) \mathrm{d} x} \\
(\text { 但し, } \mathrm{i}=\xi t)
\end{gathered}
$$

この式は時間との関係が明示的でないが, 粒子径の 個数基準頻度分布関数 $f(x)$ を個数基準矩形分布とし, $x / a=\varepsilon_{\max }, \varepsilon_{\max }=1, \varepsilon_{\min }=0$ を境界条件とすると, 網上粒子群の網上残留率は, ふるい分け時間の指数関 数となることが示される。（Appedix 2参照）

$$
\begin{aligned}
R_{\mathrm{i}} & =4 \int_{0}^{1} \varepsilon^{3} \exp \left\{-i(1-\varepsilon)^{2}\right\} \mathrm{d} \varepsilon \\
& \cong \exp \left(-\frac{i=\xi t}{15}\right)
\end{aligned}
$$

この式が成立つのは, 厳密には試行数 $\mathrm{i}$ がきわめて 小さい場合であり, 試行数 i が大きくなる場合には, 指数関数を級数展開し項別積分によって網上残留率を 求めることができる。

Fig. 3 は, 試行数と網上残留率の関係を示したもの であり, 試行数 i が増えるに従い直線に近づき, 決定

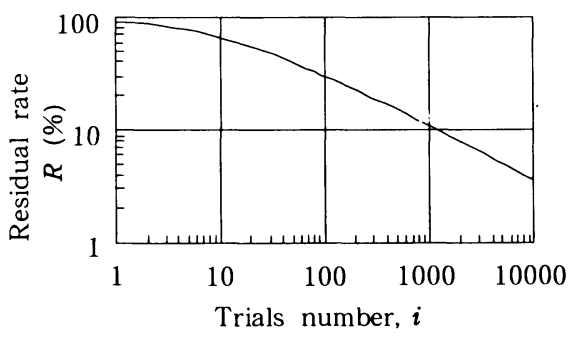

Fig. 3 Relationship between trials number and residual rate

係数R.R. が 0.999 以上の精度で次のような指数関数で 表すことができる。

$$
\begin{gathered}
R=245.8 i^{-0.45407} \quad(100 \leq i \leq 1000) \\
R \cdot R \cdot=0.999697 \\
R=308.1 i^{-0.48697} \quad(1000 \leq i \leq 10000) \\
R . R .=0.999967 \\
R=398.2 i^{-0.51232} \quad(10000 \leq i) \\
R . R .=0.999917
\end{gathered}
$$

試行数がきわめて大きくなると, 網上残留率は試行 数のほほ $1 / \sqrt{t}$ に比例するとした Fagerholt の研究結 果が誘導でき, ふるい分け過程の二段階説の一つであ る大きい粒子の通過過程にも三輪のモデルの適用が可 能となる。

\section{2 粒度測定モデル}

(1) 水谷のモデル4) との関係

通常，粉体の粒度分布はプロセスや製品の品質に大 きく影響するが, 粒度測定の精度に関する検定方法が 確立していない中で, ふるい分けの精度に関する水谷 の研究は先駆的である。

水谷のモデルは, $\mathrm{m}$ 個の網目の異なるふるいの網上 残留率が連立線形微分方程式となる, とするものであ る。なお, サンプル重量を 1 とする。

$$
\begin{aligned}
& \frac{\mathrm{d} y_{\mathrm{t}, 1}}{\mathrm{~d} t}=-K_{1} y_{\mathrm{t}, 1} \\
& \frac{\mathrm{d} y_{\mathrm{t}, \mathrm{j}}}{\mathrm{d} t}=K_{\mathrm{j}-1} y_{\mathrm{t}, \mathrm{j}-1}-K_{\mathrm{j}} y_{\mathrm{t}, \mathrm{j}}
\end{aligned}
$$

比例定数 $K_{\mathrm{j}}$ はふるい分け継続時間 $\tau$ における網上残 留率 $y_{\tau, \mathrm{j}}$ から $K_{\mathrm{j}}=\ln y_{\tau, \mathrm{j}} / \tau$ で定義されている。受血に 蓄積する量も $t=0$ で $y_{0, \mathrm{~m}+1}=0$ の初期条件のもとで次式 を解くと得られる。 


$$
\frac{\mathrm{d} y_{\mathrm{t}, \mathrm{m}+1}}{\mathrm{~d} t}=-K_{\mathrm{m}} y_{\mathrm{t}, \mathrm{m}}
$$

このモデルは，数理的表記に優れているもののふる い分けに関する現象論的な扱いがなされていないなど の欠点がある。

三輪の確率モデルを拡張した本方法による基礎式 は, Eq.(14)より次のように書くことができる。

$$
\begin{aligned}
y_{\mathrm{t}, \mathrm{j}} & =\left(1-V_{\mathrm{j}-1}\right) \cdot 1 \cdot y_{\mathrm{t}-1, \mathrm{j}-1}+V_{\mathrm{j}} \cdot 1 \cdot y_{\mathrm{t}-1, \mathrm{j}} \\
& =\left(1-V_{\mathrm{j}-1}\right) y_{\mathrm{t}-1, \mathrm{j}-1}+V_{\mathrm{j}} y_{\mathrm{t}-1 . \mathrm{j}}, \quad(\mathrm{j}=1,2, \ldots, \mathrm{m})
\end{aligned}
$$

時刻 $t$ から $t+\Delta t$ となったときを考えると，1- $V_{\mathrm{j}}$ は 単位時間あたりの網を通過する量であるから， $\Delta t$ に おける $j$ 段のふるいの網上残留率の変化は, 次式で表 される。

$$
\begin{aligned}
& y_{\mathrm{t}+\Delta t, \mathrm{j}}-y_{\mathrm{t}, \mathrm{j}}=\left(1-V_{\mathrm{j}-1}\right) \Delta t y_{\mathrm{t}, \mathrm{j}-1}-\left(1-V_{\mathrm{j}}\right) \Delta t y_{\mathrm{t}-1, \mathrm{j}} \\
& \frac{\Delta y_{\mathrm{t}, \mathrm{j}}}{\Delta t}=\frac{y_{\mathrm{t}+\Delta \mathrm{t}, \mathrm{j}}-y_{\mathrm{t}, \mathrm{j}}}{\Delta t}=\left(1-V_{\mathrm{j}-1}\right) y_{\mathrm{t}, \mathrm{j}-1}-\left(1-V_{\mathrm{j}}\right) y_{\mathrm{t}, \mathrm{j}}
\end{aligned}
$$

ところで, Eq.(20) の検討から $V_{\mathrm{j}}=1-\xi_{a_{\mathrm{j}}}\left\{\left(a_{\mathrm{j}}-x\right) / a_{\mathrm{j}}\right\}^{2}$ であり, $K_{\mathrm{j}}=\xi_{a_{1}}\left\{\left(a_{\mathrm{j}}-x\right) / a_{\mathrm{j}}\right\}^{2}$ とすると

$$
\mathrm{d} y_{\mathrm{t}, \mathrm{j}} / \mathrm{d} t=K_{\mathrm{j}-1} y_{\mathrm{t}, \mathrm{j}-1}-K_{\mathrm{j}} y_{\mathrm{t}, \mathrm{j}}
$$

となり, 水谷の式が得られる。本方法は, 網の目開き や粒子径が変化した場合の一般的手法へと拡張でき る。

\section{（2）ふるい分け完了時間}

粒度測定をふるい分け操作で行う場合には, 最下段 のふるい分けが分離の目安になり, 受皿の残量変化に よってふるい分けの精度を知ることができる。

本研究による誘導式に基づいてふるい分けの精度を 検討する。Table 2に示すように, 本サンプルの粒度 測定では，ふるい分けの進行にともなって受皿に蓄積 する量が $125 \mu \mathrm{m}$ ふるい下全量に近つくく。この相対比 が分離度を表す指標とし，完全に分離が完了した場合 を分離度 100 とする。

水谷の実験に従って，8段のふるいによる粒度測定 での受皿の蓄積量を数値計算によって求めた。（Fig.

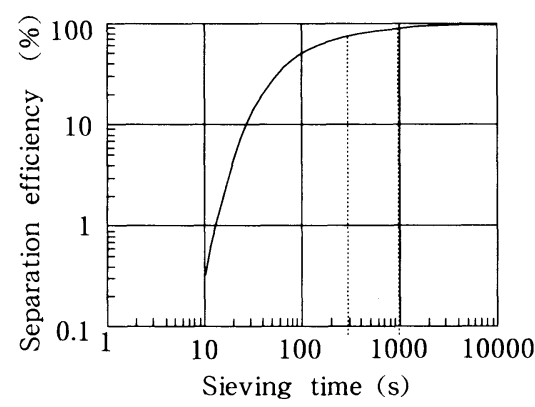

Fig. 4 Efficiency curve of screening

4参照)

通常用いられる5分間のふるい分け時間では, $73.1 \%$ \%ん達していない。また，15分でも $85.4 \%$ である。ふるい分け機においては，50\%ふるい分け が基本原理であるが, 粒度測定は粉体プロセスの最適 性や製品の品質に影響を及ぼすところから，正確性が 要求されるため, $\xi$ の測定結果を用いて粒度分布の推 定が可能である。

粒度分布式がほぼ既知である場合には，二つの異な ったふるい分け精度, 一定時間でふるい分けられた各 ふるいの粒度測定結果に基づき, 各段の分離度を仮定 して粒度分布による分離度が一致するまで繰り返し計 算を行い, 一致点の粒度分布が最終的な粒度分布とし て求めることができる。

\section{6. 結言}

基礎的な粉体の分離操作である粉体のふるい分けを 情報理論によってモデル化したところ, 三輪が提案し た関係式が誘導され，この式はふるい分けの速度論的 研究を包含することも明らかにした。

さらに，多段ふるい分けに拡張することにより，従 来明らかでなかった単位時間試行数 $\xi$ の物理的意味 と, 測定法に対する理論を提案し、これに基づき粒度 測定の精度の検証方法を示した。

本研究はシャノンの情報理論によるところが大き く, この概念で他の分野が捉えられることを確認し た。確率のみで物理現象を捉えることは危険である が, 新しい概念で既存の知見を整理することは, 工学 の分野において極めて重要であり,この手法は, 粉体 と他の工学の知見の融合に有益だと思われる。 


\section{Nomenclature}

$\boldsymbol{A}$ : channel matrix

$A_{0}^{\prime}$ : coefficient depend on the characteristics of the screening size $a$ and particle size

$a$ : opening size

$B_{a}^{\prime}$ : coefficient depend on the characteristics of the screening size $a$ and particle size

$E \quad$ : expected value

$H \quad$ : entropy

$i \quad:$ trials number

$K$ : coefficient defined by Andreasen and Mizutani

$P_{\mathrm{i}} \quad$ : probability that will remain on the $j$ th screening

$R$ : residual rate
(-) R.R. : coefficient of determination

$r_{\mathrm{i}} \quad$ : residual rate at trial number $i$

$V_{\text {i }}$ : index that will show hardness degree of passing through the $j$ th screening in unit trial ( $1 /$ trial)

$V_{j}$ : index that will show hardness degree of passing through the $j$ th screening in unit time $(1 / \mathrm{s})$

$(1 /$ trial $) \quad x \quad$ : particle size

$(\mu \mathrm{m})$

(-) $y$ : probability that will remain in bacth screening $\alpha, \alpha^{*}:$ undetermined coefficient

$\beta$ : trials number

$\varepsilon \quad$ : ratio of particle size by opening size

$\xi \quad$ : trials number in unit time

$\tau$ : screening time

\section{Appendix 1}

時間 $t$ における $j=1$ の網上残留率は, Eq.(15) で誘導されて いる。 $j \geq 2$ のときの $j-1$ 段目の網上残留率を次のように仮定す る。

$$
y_{\mathrm{L}, \mathrm{j}-1}=\prod_{\mathrm{i}=1}^{\mathrm{j}-2}\left(1-V_{\mathrm{i}}\right) \sum_{k=1}^{\mathrm{j}-1} \frac{V_{k}^{\mathrm{k}}}{\prod_{\mathrm{l}=1,1 \neq k}^{\mathrm{j}-1} V_{k}-V_{\mathrm{I}}}
$$

$j$ 段での網上残留率は, Eq. (26) の第 2 項を展開すると得ら れる。

$$
\begin{aligned}
y_{\mathrm{t}, \mathrm{j}} & =\left(1-V_{\mathrm{j}-1}\right) y_{\mathrm{t}-1, \mathrm{j}-1}+V_{\mathrm{j}} y_{\mathrm{t}-1, \mathrm{j}} \\
& =\left(1-V_{\mathrm{j}-1}\right) y_{\mathrm{t}-1, \mathrm{j}-1}+V_{\mathrm{j}}\left\{\left(1-V_{\mathrm{j}-1}\right) y_{\mathrm{t}-2, \mathrm{j}-1}+V_{\mathrm{j}} y_{\mathrm{t}-2 . \mathrm{j}}\right\} \\
& =\left(1-V_{\mathrm{j}-1}\right) V_{\mathrm{j}}^{\mathrm{t}-1}\left(\frac{y_{\mathrm{t}-1 . \mathrm{j}-1}}{V_{\mathrm{j}}^{\mathrm{t}-1}}+\frac{y_{\mathrm{t}-2, \mathrm{j}-1}}{V_{\mathrm{j}}^{\mathrm{t}-2}}+\frac{y_{\mathrm{t}-3, \mathrm{j}-1}}{V_{\mathrm{j}}^{1-3}}+\cdots \cdots\right)
\end{aligned}
$$

Eq.(A-2) の括孤の中は, Eq.(A-1) から次式のように表せ る。

$$
\frac{y_{\mathrm{t}-1, \mathrm{j}-1}}{V_{\mathrm{j}}^{\mathrm{i}-1}}=\prod_{\mathrm{i}=1}^{\mathrm{j}-2}\left(1-V_{\mathrm{i}}\right) \sum_{k=1}^{\mathrm{j}-1} \frac{1}{\prod_{\mathrm{i}=1,1 \neq k}^{\mathrm{j}-1} V_{k}-V_{\mathrm{i}}}\left(\frac{V_{k}}{V_{\mathrm{j}}}\right)^{1-1}
$$

ところで,

$$
\sum_{k=1}^{\mathrm{j}-1}\left(\frac{V_{k}}{V_{\mathrm{j}}}\right)^{t-1}=\frac{V_{k}}{V_{\mathrm{j}}} \frac{1-\left(\frac{V_{k}}{V_{\mathrm{j}}}\right)^{t-1}}{1-\frac{V_{k}}{V_{\mathrm{j}}}}=\frac{V_{k}}{V_{\mathrm{j}}^{t-1}} \cdot \frac{V_{\mathrm{j}}^{\mathrm{t}-1}-V_{k}^{t-1}}{V_{\mathrm{j}}-V_{k}}
$$

となるから，整理すると次式を得る。

$$
\begin{array}{r}
y_{\mathrm{t} . \mathrm{j}}=\prod_{\mathrm{i}=1}^{\mathrm{j}-1}\left(1-V_{\mathrm{i}}\right) \sum_{k=1}^{\mathrm{j}-1}\left(\frac{-V_{k} V_{\mathrm{j}}^{\mathrm{t}-1}}{\prod_{\mathrm{l}=1,1 \neq k}^{j-1}\left(V_{k}-V_{\mathrm{i}}\right)\left(V_{k}-V_{\mathrm{j}}\right)}\right. \\
\left.+\frac{V_{k}^{\mathrm{l}}}{\prod_{\mathrm{i}=1,1 \neq k}^{\mathrm{j}-1}\left(V_{k}-V_{\mathrm{i}}\right)\left(V_{k}-V_{\mathrm{j}}\right)}\right)
\end{array}
$$

$$
\sum_{k=1}^{j} \frac{V_{k}}{\prod_{1=1,1 \neq k}^{i-1}\left(V_{k}-V_{1}\right)}
$$

は $k=j$ の項とそれ以外の項に分けることができ，部分分数の 性質を利用すると，次のように簡単化できる。

$$
\sum_{k=1}^{j} \frac{V_{k}}{\prod_{\mathrm{l}=1,1 \neq k}^{j}\left(V_{k}-V_{\mathrm{l}}\right)}=\frac{V_{\mathrm{j}}}{\prod_{l=1}^{j-1}\left(V_{\mathrm{j}}-V_{\mathrm{l}}\right)}+\sum_{k=1}^{\mathrm{j}-1} \frac{V_{k}}{\prod_{\mathrm{l}=1,1 \neq k}^{\mathrm{j}-1}\left(V_{k}-V_{\mathrm{l}}\right)}=0
$$

Eq.(A-3) における括弧の中の第 1 項に, Eq.(A-4) を代入す る。

$$
\sum_{k=1}^{j-1} \frac{-V_{k} V_{\mathrm{j}}^{\mathrm{i}-1}}{\prod_{\mathrm{l}=1,1 \neq k}^{-1}\left(V_{k}-V_{\mathrm{l}}\right)\left(V_{k}-V_{\mathrm{j}}\right)}=\frac{V_{\mathrm{j}}^{\mathrm{l}}}{\prod_{\mathrm{l}=1,1 \neq \mathrm{j}}^{\mathrm{h}}\left(V_{\mathrm{j}}-V_{\mathrm{i}}\right)}
$$

また，Eq. (A-3) の第 2 項は $k=j-1$ までの值である。従っ て，第 1 項，第 2 項を合わせると

$$
y_{\mathrm{L}, \mathrm{j}}=\prod_{\mathrm{i}=1}^{\mathrm{j}-1}\left(1-V_{\mathrm{i}}\right) \sum_{k=1}^{\mathrm{j}} \frac{V_{k}^{\mathrm{t}}}{\prod_{\mathrm{l}=1,1 \neq k}^{j} V_{k}-V_{\mathrm{i}}}
$$

が誘導される。

最終段も, Eq.(26) から,

$$
y_{\mathrm{t}, \mathrm{m}+1}=\left(1-V_{\mathrm{m}}\right) y_{\mathrm{t}-1, \mathrm{~m}}+y_{\mathrm{t}-1, \mathrm{~m}+\mathrm{l}}=\left(1-V_{\mathrm{m}}\right) \sum_{\tau=0}^{\mathrm{t}-1} y_{\tau, \mathrm{m}}
$$

となり, $m$ 段の $\tau=0$ から $\tau=t-1$ までの残留確率を求めること になる。

$$
\begin{array}{r}
y_{\mathrm{l}, \mathrm{m}+1}=\prod_{\mathrm{i}=1}^{\mathrm{m}}\left(1-V_{\mathrm{i}}\right) \cdot\left\{\frac{\sum_{\tau=0}^{\mathrm{t}-1} V_{\mathrm{i}}^{\tau}}{\left(V_{1}-V_{2}\right) \cdots\left(V_{1}-V_{\mathrm{m}}\right)}\right. \\
+\frac{\sum_{\tau=0}^{\mathrm{t}-1} V_{2}^{\tau}}{\left(V_{2}-V_{1}\right) \cdots\left(V_{2}-V_{\mathrm{m}}\right)}+\cdots
\end{array}
$$

一方, 


$$
\left.+\frac{\sum_{\tau=0}^{1-1} V_{m}^{\tau}}{\left(V_{m}-V_{1}\right) \cdots\left(V_{m}-V_{m-1}\right)}\right\}
$$

となる。部分分数を利用して整理すると次式を得る。

\section{Appendix 2}

Eq.(22)をTaylor 展開する。

$$
R_{\mathrm{i}}=4 \int_{0}^{1} 3\left(1-i(1-\varepsilon)^{2}+\frac{i^{2}(1-\varepsilon)^{4}}{2 !}-\frac{i^{3}(1-\varepsilon)^{6}}{3 !}+\cdots\right) \mathrm{d} \varepsilon
$$

$$
\begin{aligned}
& y_{\mathrm{t}, \mathrm{m}+1}=1-\prod_{i=1}^{m}\left(1-V_{\mathrm{i}}\right) \cdot \cdot \frac{V_{\mathrm{i}}^{t}}{\left(V_{1}-V_{2}\right) \cdots\left(V_{1}-V_{\mathrm{m}}\right)\left(1-V_{1}\right)} \\
& \left.+\frac{V_{\mathrm{m}}^{\mathrm{l}}}{\left(V_{\mathrm{m}}-V_{1}\right) \cdots\left(V_{\mathrm{m}}-V_{\mathrm{m}-1}\right)\left(1-V_{\mathrm{m}}\right)}\right)
\end{aligned}
$$

\section{References}

1) Miwa, S. : "Evaluation of sieving efficiency", Kagaku Kogaku, 24, 150 155 (1960)

2) Miwa, S. : "Funtaino Furuiwake", pp.170 206, Nikkan Kogyo (1969)

3) Miwa, S. : "Furuiwake Tokuhon", Sangyo Gijutsu Center (1974)

4) Mizutani, S. : "An experimental consideration of accuracy of sieving analysis", Journal of Earth Science,
(Nagoya Univ.) 11, 1 7 (1963)

5) Taki, Y. : “Jouhouron 1", pp.88 91, Iwanami Shoten (1995)

6) Ohishi, S. : "Reinimotozuku Jouhouriron Nyuumon", pp.70 72, Koudansha Science (1995)

7) Takekuma, R. : "Kakuritsu”, pp.70 72, Baifuukan (1995) 